\title{
PENGUATAN KARAKTER PESERTA DIDIK MELALUI PEMBELAJARAN AGAMA ISLAM BERBASIS MULTIKULTURAL DI SMAN 1 JOMBANG
}

\author{
Elik Khoirun Nisa \\ Universitas KH. A. Wahab Hasbullah Tambakberas \\ e-mail: elikkhoir4@gmail.com. \\ Mukani \\ Guru SMAN 1 Jombang \\ e-mail: mlorah42@gmail.com.
}

\begin{abstract}
Indonesia has many cultures, customs, tribes, nations and religions. This diversity can lead to conflict, because of incompatibility between individuals with other in accepting the differences. This article discusses the diversity and the role of Islamic religious teachers in implementing multicultural education at SMAN 1 Jombang. The design of this study is qualitative, using such instruments as interviews, observation and documentation. Data analysis in this research is reduction, display and conclusion (verification). This research result concludes that the conditions at SMAN 1 Jombang are very diverse, in terms of ethnicity, religion, social status and thinking patterns. Such tribes in the school as Java, Padang, Bugis, Sunda and Madura, then the religion includes Islam, Catholicism and Protestantism. All three are different in their belief and teaching of groups adopted. The leader of school gives freedom to all school citizen to worship and actualize based on their beliefs, so there has never been a conflict led to the diversity. This is because of the role of Islamic religion teachers and others in encouraging multicultural learning based and then resulted character tolerance can grow in the minds and actions of all school members.
\end{abstract}

Keyword: Character Education, Multicultural, PAI Teachers Role

\section{PENDAHULUAN}

Sebagai negara kepulauan terluas di dunia, Indonesia memiliki kekayaan melimpah, baik sumber daya alam maupun sumber daya manusia. Indonesia merupakan bangsa terkaya dengan keragaman budaya, bahasa, adat istiadat, suku, bangsa dan agama yang hidup secara berdampingan. Menjaga kekayaan budaya, adat istiadat dan mengenal suku bangsa di Indonesia adalah salah satu upaya meningkatkan jiwa nasionalisme, memperluas wawasan nusantara dan mempersatukan bangsa Indonesia sesuai dengan semboyan Bhinneka Tunggal Ika. Meski sebagai kota santri, Jombang juga merepresentasikan keberagaman tersebut, 


\section{Elik Khoirun Nisa-Mukani}

terutama dalam perspektif agama yang dipeluk wargnya. Di wilayah Jombang, terdapat empat pondok pesantren besar dan tua, yaitu Tambakberas, Tebuireng, Peterongan dan Denanyar. Fakta di lapangan menunjukkan bahwa warga Jombang, selain agama Islam, juga memeluk Kristen, Protestan, Hindu, Budha dan Konghucu. Jombang tidak hanya memiliki penduduk lokal, yang berasal dari suku Jawa, tetapi juga masyarakat yang multikultural. Faktor ini yang mendorong Jombang pada bulan Oktober 2017 lalu ditunjuk sebagai tuan rumah penyelenggaraan ASEAN Youth Interfaith Camp (AYIC), yang diikuti perwakilan pemuda dari 11 negara. ${ }^{1}$

Artikel ini akan mengkaji SMAN 1 Jombang dalam konteks keberagaman agama yang dipeluk peserta didiknya, termasuk latar belakang suku dan strata sosial. Pada satu agama yang dipeluk sendiri, Islam sebagai contohnya, juga beragam pula aliran yang dianut, seperti NU, Muhammadiyah, LDII, Shidiqiyah, Wahidiyah dan lain sebagainya. Hal ini menarik diungkap karena Jombang sebagai barometer dalam melihat toleransi kehidupan yang ditunjukkan warganya, termasuk yang terjadi di sebuh lembaga pendidikan resmi milik pemerintah bernama SMAN 1 Jombang.

Tulisan ini akan memfokuskan kajian kepada potret keberagaman yang terjadi di objek SMAN 1 Jombang dari perspektif agama yang dianut dan latar belakang suku. Artikel ini juga mengupas peran guru agama Islam dalam menjaga toleransi yang sudah dibangun melalui pendidikan karakter berbasis multikultural.

\section{PEMBAHASAN}

\section{Pendidikan Multikultural}

Pendidikan multikultural berasal dari dua kata, yaitu pendidikan dan multikultural. Pendidikan merupakan proses pengembangan sikap dan tata laku seseorang atau sekelompok orang dalam usaha mendewasakan manusia melalui pengajaran, pelatihan, proses, perbuatan dan cara-cara yang mendidik. Di sisi lain pendidikan adalah transfer of knowledge atau memindah ilmu pengetahuan. Multikultural secara etimologis berasal dari kata multi, yang berarti banyak, beragam dan aneka, sedangkan kultural berasal dari kata culture, yang berarti budaya, tradisi, kesopanan atau pemeliharaan. Rangkaian kata pendidikan dan multikultural memberikan arti secara terminologis adalah proses pengembangan seluruh potensi manusia yang menghargai pluralitas dan heterogenitasnya sebagai

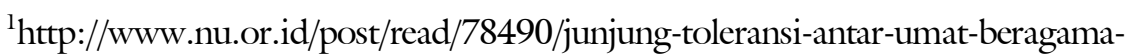
jombang-tuan-rumah-ayic-2017. Diakses 22 Juni 2017.

92 | Falasifa, Vol. 9 Nomor 2 September 2018 
konsekuensi keragaman budaya, etnis, suku dan aliran (agama). ${ }^{2}$

Pendidikan multikultural adalah suatu cara untuk mengajarkan keragaman (teaching diversity). Pendidikan multikultural menghendaki rasionalisasi etis, intelektual, sosial dan pragmatis secara inter-relatif, yaitu mengajarkan ideal inklusivisme, pluralisme dan saling menghargai semua orang. ${ }^{3}$ Ainurrafiq Dawam menjelaskan bahwa pendidikan multikultural adalah proses pengembangan seluruh potensi manusia yang menghargai pluralitas dan heterogenitasnya sebagai konsekuensi keberagaman budaya, etnis, suku dan aliran. Pemikiran pendidikan multikultural yang demikian tentu memiliki implikasi yang sangat luas dalam pendidikan. Harapannya adalah terciptanya kedamaian sejati, keamanan yang tidak dihantui kecemasan dan kebahagiaan tanpa rekayasa. ${ }^{4}$

Pendidikan multikultural diharapkan dapat menyelesaikan persoalan konflik yang terjadi di masyarakat, atau paling tidak mampu memberikan penyadaran kepada masyarakat bahwa konflik bukan suatu hal yang baik untuk dibudayakan. Selanjutnya pendidikan juga harus mampu memberikan tawaran-tawaran yang mencerdaskan, antara lain dengan cara mendesain materi, metode, hingga kurikulum yang mampu menyadarkan masyarakat tentang pentingnya sikap saling toleran, menghormati perbedaan suku, agama, ras, etnis dan budaya masyarakat Indonesia yang multikultural. ${ }^{5}$

Di Indonesia, pendidikan multikultural relatif baru dikenal sebagai suatu pendekatan yang dianggap lebih sesuai bagi masyarakat Indonesia yang heterogen, terlebih pada masa otonomi dan desentralisasi yang baru dilakukan. Pendidikan multikultural yang dikembangkan di Indonesia sejalan dengan pengembangan demokrasi yang dijalankan sebagai counter terhadap kebijakan desentralisasi dan otonomi daerah. ${ }^{6}$

Meskipun demikian, pendidikan multikultural secara umum memiliki tiga karakteristik. Pertama adalah berprinsip pada demokrasi, kesetaraan dan keadilan. Kedua adalah berorientasi kepada kemanusiaan, kebersamaan dan kedamaaian. Ketiga adalah mengembangkan sikap mengakui, menerima dan menghargai

${ }^{2}$ Zakiyuddin Baidhawy, Pendidikan Agama Berwasan Multikultural (Jakarta: PT Gelora Aksara Pratama, 2003), 136.

${ }^{3} \mathrm{Ibid}, 8$.

${ }^{4}$ Ngainun Naim dan Ahmad Syauqi, Pendidikan Multikultural Konsep dan Aplikasi, (Yogyakarta: Ar-Ruuz Media, 2010), 50.

${ }^{5}$ Tri Astutik Haryati, "Islam dan Pendidikan Multikultural," Jurnal Tadris, Vol. 2 (2009), 28.

${ }^{6}$ Sapendi, "Internalisasi Nilai-nilai Multikultural dalam Pembelajaran Pendidikan Agama Islam di Sekolah,” Raheema: Jumal Studi Gender dan Anak, (tt.), 94. 
keragaman. $^{7}$ Dalam konteks pendidikan agama, karakteristik pendidikan multikultural adalah belajar hidup dalam perbedaan, membangun saling percaya (mutual trust), memelihara saling pengertian (mutual understanding), menjunjung sikap saling menghargai (mutual respect), terbuka dalam berpikir, apresiasi dan interdependensi, resolusi konflik dan rekonsiliasi nirkekerasan. ${ }^{8}$

Pada perspektif lain, pendidikan multikultural setidaknya memiliki tiga pendekatan. Pertama adalah tidak lagi menyamakan pandangan pendidikan (education) dengan sekolahan (schooling), atau pendidikan multikultural dengan program-program sekolah formal. Kedua adalah menghindari pandangan yang menyamakan kebudayaan dengan kelompok etnik. Ketiga adalah pengembangan kompetensi dalam suatu kebudayaan baru membutuhkan interaksi inisiatif dengan orang-orang yang sudah memiliki kompetensi, maka dapat dilihat lebih jelas bahwa upaya untuk mendukung sekolah-sekolah yang terpisah secara etnik merupakan anti etnis terhadap tujuan pendidikan multikultural. ${ }^{9}$

Tujuan pendidikan multikulktural, menurut Gorsk, adalah setiap siswa memiliki kesempatan untuk mengembangkan prestasi mereka, siswa belajar bagaimana belajar dan berpikir secara kritis, mendorong siswa untuk mengambil peran aktif dalam pendidikan, dengan menghadirkan pengalaman-pengalaman mereka dalam konteks belajar. Menurut Gorsk, pendidikan multicultural juga untuk mengakomodasikan semua gaya belajar siswa, mengapresiasi kontribusi dari kelompok-kelompok yang berbeda, mengembangkan sikap positif terhadap kelompok-kelompok yang memiliki latar belakang berbeda, untuk mengembangkan identitas etnis, nasional dan global serta mengembangkan keterampilan-keterampilan mengambil keputusan dan analisis secara kritis sehingga siswa dapat membuat pilihan yang lebih baik dalam kehidupan seharihari. ${ }^{10}$

\section{Peran Guru Agama Islam}

Kajian tentang guru sangat luas, dalam keseluruhan proses pendidikan, khususnya proses pembelajaran di sekolah maupun di madrasah, guru memegang peran penting di dalam proses pendidikan. Dalam konteks pendidikan Islam,

${ }^{7}$ Abdullah Aly, Pendidikan Islam Multikultural di Pesantren (Yogyakarta: Pustaka Pelajar, 2011), 103.

${ }^{8}$ Zakiyuddin Baidhawy, Pendidikan Agama Berwasan Multikultural, 78.

${ }^{9}$ Choirul Machfud, Pendidikan Multikultural (Yogyakarta: Pustaka Pelajar, 2016), 192.

${ }^{10}$ Rustam Ibrahim, "Pendidikan Multikultural: Pengertian, Prinsip dan Relevansinya dengan Tujuan Pendidikan Islam," Jumal Addin, Vol. 1, 144.

94 | FALASIFA, Vol. 9 Nomor 2 September 2018 
pendidik disebut dengan murabbi, mu'allim dan muaddib. Ketiga term itu, memiliki makna berbeda, sesuai dengan konteks kalimat, meskipun dalam situasi tertentu memiliki kesamaan makna. Kata murabbi, misalnya, sering dijumpai dalam kalimat yang orientasinya lebih mengarah kepada pemeliharaan, baik yang bersifat jasmani atau rohani. Istilah mu'allim, pada umumnya digunakan dalam membicarakan aktivitas yang lebih terfokus kepada pemberian atau pemindahan ilmu pengetauan, dari seorang yang tahu kepada seseorang yang tidak tahu. Sedangkan istilah mu'addib, menurut al-Attas, lebih luas dari istilah mu'allim' dan lebih relevan dengan konsep pendidikan Islam. ${ }^{11}$

Secara fungsional, pendidik menunjukkan kepada seseorang yang melakukan kegiatan dan memberikan pengetahuan, keterampilan, pendidikan, pengalaman dan lain sebagainya. Orang yang melakukan kegiatan ini bisa siapa saja dan kapan saja. Berdasarkan pengertian ini, maka yang termasuk dalam pendidik itu bisa kedua orang tua, guru, tokoh masyarakat dan lain sebagainya, ${ }^{12}$ tergantung posisi saat seseorang itu belajar.

Banyak ahli pendidikan memberi batasan sebagai calon seorang pendidik, khususnya dalam lembaga pendidikan formal. Menurut Zakiyah Darajat, calon guru harus memenuhi beberapa persyaratan, seperti bertakwa kepada Allah Swt, berilmu, sehat jasmani, berkelakukan baik, memiliki bakat sebagai guru, berkepribadian luas, bermental sehat, berpengalaman, berpengetahuan luas, berjiwa Pancasila dan seorang warga negara yang baik. ${ }^{13}$ Ahmad Tafsir, sebagaimana mengutip pendapat Soejono, menyatakan bahwa syarat guru adalah sudah dewasa tentang umur, sehat jasmani dan rohani, ahli dalam mengajar, berdedikasi tinggi dan berkesusilaan. ${ }^{14}$

Tugas guru agama Islam sangat berat, karena tidak hanya memberikan berupa materi dan pengetahuan, tetapi juga pada investasi nilai-nilai moral dan spiritual yang diemban untuk ditransformasikan ke arah pembentukan kepribadian peserta didik. Guru dituntut mampu membimbing, melatih dan membiasakan peserta didik berprilaku yang baik. Syaiful Sagala, mengutip pendapat Roestiyah, menyatakan bahwa tugas guru secara garis besar, yaitu mewariskan kebudayaan dalam betuk kecakapan dan pengalaman empirik, membentuk kepribadian anak didik sesuai dengan dasar negara, memfungsikan diri sebagai media dan perantara

\footnotetext{
${ }^{11}$ Ramayulis, Ilmu Pendidikan Islam (Jakarta: Kalam Mulia, 2010), 56.

${ }^{12}$ Abudin Nata, Filsafat Pendidikan Islam (Jakarta: Katalog dalam Terbitan, 2005), 114.

${ }^{13}$ Zakiyah Darajat, Ilmu Pendidikan Islam (Jakarta: Bumi Aksara, 2011), 41.

${ }^{14}$ Ahmad Tafsir, Ilmu Pendidikan Dalam Perspektif Islam (Bandung: PT. Remaja Rosdakarya, 2010), 80.
} 


\section{Elik Khoirun Nisa-Mukani}

pembelajaran bagi masyarakat lingkungan, memfungsikan diri sebagai administrator dan sekaligus manager yang disenangi. ${ }^{15}$

Para ahli pendidikan Islami juga ahli pendidikan Barat telah sepakat bahwa tugas guru adalah mendidik. Mendidik itu sebagian dilakukan dalam bentuk mengajar, sebagian memberikan dalam bentuk memberikan dorongan, memuji, menghukum, memberi contoh, membiasakan dan lain sebagainya. ${ }^{16}$ Tugas-tugas selain mengajar, yaitu tugas membuat persiapan mengajar, tugas mengevaluasi hasil belajar dan yang bersangkutan dengan pencapaian tujuan pengajaran.

Moh. Uzer Usman mengemukakan, guru memiliki banyak tugas, baik yang terikat oleh dinas maupun di luar dinas, meliputi dalam bentuk pengabdian. Tugas guru sebagai profesi meliputi mendidik, mengajar dan melatih. Mendidik berarti meneruskan dan mengembangkan nilai-nilai hidup. Mengajar berarti meneruskan dan mengembangkan ilmu pengetahuan dan teknologi. Sedangkan melatih berarti mengembangkan keterampilan-keterampilan kepada siswa. Tugas guru dalam kemanusiaan meliputi bahwa guru di sekolah harus dapat menjadikan dirinya sebagai orang tua kedua. Guru harus mampu menarik simpati sehingga menjadi idola para siswanya. Pelajaran apapun yang diberikan, hendaknya dapat menjadi motivasi bagi siswanya dalam belajar. Tugas guru dalam masyarakat adalah mencerdaskan bangsa menuju pembentukan manusia Indonesia seutuhnya yang berdasarkan Pancasila. ${ }^{17}$

Tanggung jawab guru agama Islam, mengutip pendapat Syaiful Sagala, menyebutkan ada beberapa poin yang menjadi tanggung jawab seorang guru, antara lain mematuhi norma dan nilai kemanusiaan, menerima tugas mendidik bukan sebagai beban, tetapi dengan gembira dan sepenuh hati dan bersikap arif bisaksana dan cermat serta hati-hati. ${ }^{18}$

Menurut Oemar Hamalik, tanggung jawab guru di antaranya adalah menuntut murid-murid untuk belajar, turut serta membina kurikulum sekolah, melakukan pembinaan terhadap diri siswa, memberikan bimbingan terhadap murid, melakukan diagnosis atau kesulitan-kesulitan belajar dan mengadakan penilaian atas kemajuan belajar, menyelenggarakan penelitian, mengenal masyarakat dan ikut serta aktif menghayati, mengamalkan, dan mengamankan Pancasila. ${ }^{19}$ Berdasarkan beberapa pendapat tersebut di atas dapat diambil

\footnotetext{
${ }^{15}$ Syaiful Sagala, Kemampuan Profesional Guru dan Tenaga Kependidikan (Bandung: Alfabeta, 2009), 12.

${ }^{16}$ Ahmad Tafsir, Ilmu Pendidikan Islami, 125.

${ }^{17}$ Moh. Uzer Usman, Menjadi Guru Profesional (Bandung: Rosdakarya, 2010), 7.

${ }^{18}$ Syaiful Sagala, Kemampuan Profesional Guru, 13.

${ }^{19}$ Oemar Hamalik, Proses Belajar Mengajar (Jakarta: Bumi Aksara, 2015), 127.
}

96 | FALASIFA, Vol. 9 Nomor 2 September 2018 
kesimpulan bahwa guru harus bertanggung jawab atas segala sikap, tingkah laku dan perbuatannya dalam rangka membina jiwa dan watak anak didik, yaitu tangggung jawab moral diguru dan ditiru, yaitu diperhatikan kata-katanya dan ditiru perbuatannya.

\section{METODE PENELITIAN}

Tulisan ini adalah hasil penelitian yang dilakukan di SMAN I Jombang. Penelitian ini dilakukan mulai bulan Agustus sampai Oktober tahun 2017. Jenis penelitian yang digunakan dalam artikel ini adalah penelitian lapangan field research). ${ }^{20}$ Pendekatan yang digunakan adalah kualitatif deskriptif, yaitu penelitian non-hipotesis, sehingga dalam langkah penelitiannya tidak perlu menggunakan hipotesis. ${ }^{21}$

Kehadiran peneliti dalam penulisan artikel ini adalah sebagai instrumen sekaligus pengumpul data, karena objek dalam kajian ini adalah berupa sebuah institusi. Ketika di lapangan, penulis melakukan pengamatan, sebagaimana yang didefinisikan Bogdan, yang dikutip Moleong, bahwa pengamatan berperan sebagai penelitian serta bercirikan interaksi sosoial yang subjek dan selama itu ada dalam bentuk catatan lapangan didokumentasikan secara sistematis dan berlaku tanpa gagasan.

Sumber data pada tulisan ini dibagi menjadi dua, yaitu primer dan sekunder. Sumber data primer berupa hasil wawancara dengan kepala sekolah, guru agama Islam dan siswa SMAN 1 Jombang. Sumber data sekunder diperoleh dari data-data yang berkaitan dengan sekolah dan berbagai literatur yang relevan dengan pembahasan, termasuk dari hasil observasi.

Teknik pengumpulan data dalam artikel ini menggunakan teknik wawancara, observasi dan dokumentasi. Data yang sudah terkumpul kemudian dilakukan analisis kepadanya, sebagaimana pendapat Miles dan Hubermen, yang meliputi reduksi, penyajian (display) dan kesimpulan (verification). Untuk menjaga validitas, dilakukan uji keabsahan data, yang dilakukan melalui perpanjangan pengamatan, meningkatkan ketekunan dan triangulasi, baik sumber, teknik ataupun waktu. ${ }^{22}$

\section{HASIL PENELITIAN}

SMAN 1 Jombang berlokasi di Jalan Bupati RAA Soeroadiningrat No. 8

\footnotetext{
${ }^{20}$ Colid Narbuko dkk, Metodologi Penelitian (Jakarta: PT. Bumi Aksara, 2008), 46.

${ }^{21}$ Suharsimi Arikunto, Prosedur Penelitian (Jakarta: Rineka Cipta, 2010), 21.

${ }^{22}$ Lexy J. Moleong, Metodologi Penelitian Kualitatif (Bandung: Remaja Rosdakarya, 2010), 269-271.
}

FALASIFA, Vol. 9 Nomor 2 September 2018 | 97 


\section{Elik Khoirun Nisa-Mukani}

Jombang. Letaknya persis di jantung kota, karena berada di utara alon-alon Jombang. Sekolah ini berdiri sejak tahun 1980 berdasarkan SK Menteri Pendidikan dan Kebudayaan RI Nomor 0206 tahun 1980 tanggal 30 Juli 1980. SMAN 1 Jombang sudah memperoleh nilai akreditasi A. Pada tahun pelajaran 2017/2018, program studi yang dibuka adalah IPA dan IPS.

Visi SMAN I Jombang adalah mewujudkan insan yang berimtaq, berprestasi, berbudi pekerti, peduli lingkungan dan berwawasan global. Misi sekolah ini adalah (1) meningkatkan iman dan takwa terhadap Tuhan Yang Maha Esa, (2) meningkatkan prestasi akademik dan non-akademik, (3) membiasakan bersikap, berucap dan berperilaku yang mencerminkan budi pekerti, (4) membiasakan peduli lingkungan bersih dan sehat, (5) menumbuhkembangkan kemampuan beradaptasi terhadap masyarakat global.

\section{A. Potret Keberagaman}

Kepala SMAN 1 Jombang saat penulisan artikel ini adalah Nurhidayat, yang beragama Islam. Pada periode sebelumnya, jabatan kepala sekolah diduduki oleh Sih Wihartini, penganut Protestan dari Gereja Kristen Jawa Wetan (GKJW). Saat itu Wihartini menjabat mulai tahun 2011-2016. ${ }^{23}$

Berdasarkan hasil wawancara dengan Nurhidayat, diperoleh informasi bahwa peserta didik yang ada di SMAN 1 Jombang sangat beragam. Keragaman yang ada meliputi dari keberagaman agama dan suku. Sedangkan untuk suku yang ada meliputi suku Jawa, Bugis, Padang, Madura dan Sunda. ${ }^{24}$

Hal tersebut juga dikuatkan oleh guru agama Islam Mukani ${ }^{25}$ berikut ini:

Keragaman yang ada di SMAN 1 Jombang ini adalah meliputi keberagaman agama dan suku. Agama yang dianut oleh peserta didik meliputi agama Islam, Katolik dan Protestan. Sedangkan agama Islam sendiri terdiri dari berbagai golongan, di antaranya adalah yang Nahdhatul Ulama, Muhammadiyah, LDII dan Shiddiqiyah. Dan untuk perbedaan suku yaitu suku Jawa, Madura, Padang, Bugis. Agama Islam adalah agama mayoritas yang dianut oleh siswa, sedangkan untuk Katolik dan Protestan adalah agama minoritas, untuk siswa yang beragama Katolik ada 16 siswa, sedangkan untuk Protestan ada 9 siswa.

Meskipun dengan kondisi keberagaman yang seperti itu, tetapi pada faktanya peserta didik, guru dan semua warga sekolah mampu menjaga

\footnotetext{
${ }^{23}$ Observasi, 6 Oktober 2017.

${ }^{24}$ Nurhidayat, kepala SMAN 1 Jombang, wawancara, 6 Oktober 2017.

${ }^{25}$ Mukani, guru agama Islam SMAN 1 Jombang, wawancara, 4 Oktober 2017.
}

98 | FALASIFA, Vol. 9 Nomor 2 September 2018 
keharmonisan di sekolahan tersebut. Hal tersebut diungkapkan oleh salah satu peserta didik yang mutasi masuk dari Samarinda dan yang menganut agama Protestan, yaitu Yohana, ${ }^{26}$ berikut ini:

Kondisi di sini harmonis dan toleransi. Toleransi yang ada di sini tidak membeda-bedakan antara siswa satu dengan siswa yang lainnya, baik dalam hal suku, agama dan ras. Contohnya bahwa ketika saya pertama kali masuk kelas, saat pindahan dari Samarinda, saya tidak mengenakan kerudung, teman-teman yang lainnya bersikap biasa saja ke saya, tidak ada yang mencemooh atau bertanya ke saya tentang status saya sebagai non-muslim.

Guru agama Islam Mukani menegaskan bahwa keragaman yang terjadi di SMAN I Jombang tetap mendorong peserta didik beragama Islam untuk melaksanakan ajaran agamanya dengan benar. Peserta didik putrid wajib mengenakan hijab dan berbaju lengan panjang, namun yang beragama non-Islam tidak diwajibkan berhijab, namun tetap memakai rok dan baju lengan panjang. "Maka dari itu, ketika kita melihat ada siswa yang tidak mengenakan hijab maka dapat dipastikan bahwa ia adalah non-muslim," ujarnya. ${ }^{27}$

Keberagaman yang ada mengharuskan para peserta didik agar mampu saling toleransi antara satu dengan yang lainnya, sehingga keharmonisan tetap terjalin dengan baik. Hal tersebut diungkapkan oleh $\mathrm{Hafid}^{28}$ berikut ini:

Keharmonisan yang ada di sini sudah sangat terjaga. Sering ada acara silaturahim ke guru-guru, setiap tahun selalu ada kegiatan buka bersama, ketika ada keluarga siswa yang wafat hal yang biasa kami lakukan adalah galang dana, untuk membantu keluarga dan berbela sungkawa, bahkan alumni pun biasanya juga ikut membantu. Komunikasi kita dengan alumni masih terjaga. Sikap toleransi juga terjalin dengan baik, mayoritas agama yang dianut oleh siswa adalah lslam, tetapi di sana juga ada agama Kristen dan Protestan, biasanya ketika ada agenda keagamaan, yang Kristen juga ada agenda keagamaan sendiri. Jadi dari sekolahan juga memfasilitasi umat yang berbeda agama dalam meningkatkan pengetahuan mereka dalam beragama.

Warga sekolah dalam menghadapi perbedaan sangat toleransi sekali. Hal tersebut diungkapkan oleh Adam bahwa sikap yang dilakukan oleh para peserta didik contohnya dalam menghadapi perbedaan mereka merasa bahwa perbedaan adalah anugerah yang diberikan oleh Tuhan. Dengan adanya perbedaan mereka

\footnotetext{
${ }^{26}$ Yohana, siswa kelas XI-IPA-2, wawancara, 6 Oktober 2017.

${ }^{27}$ Mukani, guru agama Islam SMAN 1 Jombang, wawancara, 6 Oktober 2017.

${ }^{28} \mathrm{Hafid}$, siswa kelas XII-IPA-2, wawancara, 6 Oktober 2017.
} 


\section{Elik Khoirun Nisa-Mukani}

bisa menambah wawasan baru, pengetahuan baru, begitupun juga ketika ada permasalahan, sehingga permasalahannya tidak berlarut-larut, tetapi cepat diselesaikan. ${ }^{29}$

Di sisi lain, saat penulis melakukan wawancara kepada siswa yang berbeda suku, yaitu Fatih ${ }^{30}$ yang berasal dari Padang, diperoleh hasil sebagai berikut:

Toleransi antar warga sekolah sudah berjalan dengan baik, tetapi antar siswa kadang belum berjalan dengan baik, mereka kurang toleransi antara satu dengan yang lainnya, contohnya ada siswa yang memojokkan teman, tetapi toleransi beragamanya cukup baik. Islam dan Kristen walaupun berbeda tapi tidak membedakan dalam menghadapi perbedaan tersebut sikap saya sebagai seorang siswa, menjadi hal yang wajar, dan saya biasa saja, tidak ada yang dibeda-bedakan, semua teman adalah sama, melalui perbedaan tersebut kita bisa bertukar ilmu pengetahuan.

Selain hubungan antar peserta didik yang berjalan dengan baik dan harmonis, hubungan mereka dengan guru pun juga harmonis. Hal ini sebagaimana ditegaskan Nabila bahwa kondisi keharmonisan berjalan dengan baik, antara guru yang berbeda agama dengan peserta didik di sini. "Guru tidak membeda-bedakan antara siswa yang satu dan siswa yang lainnya, guru yang nonmuslim ke siswa yang muslim menghargai," ujarnya. ${ }^{31}$

Berdasarkan uraian hasil wawancara yang ada di atas, dapat diambil kesimpulan bahwa kondisi yang ada di SMAN I Jombang sangat beragam. Keberagaman tersebut meliputi keberagam suku, agama, status sosial serta pola pikir. Suku yang ada di sekolah tersebut meliputi suku Padang, Jawa, Bugis dan Madura. Sedangkan dalam hal agama, agama yang ada yaitu Islam, Katolik dan Protestan. Keberagaman yang ada tidak membuat mereka terpecah belah sehingga menimbulkan konflik, namun justru mereka saling memahami, menghormati dan toleransi antara satu dengan yang lainnya. Sekolah memberikan kebebasan kepada setiap individu untuk beraktualisasi sesuai dengan apa yang mereka inginkan. Dalam hal keberagaman agama yang ada, sekolah memfasilitasi guru agama tersendiri.

\section{B. Peran Guru Agama Islam}

Implementasi pendidikan multikultural di sekolah sangat membutuhkan peran guru agama. Termasuk juga yang terjadi di SMAN 1 Jombang. Hal ini

\footnotetext{
${ }^{29}$ Adam, siswa kelas X-IPA-2, wawancara, 5 Oktober 2017.

${ }^{30}$ Fatih, siswa kelas XI-IPA-2, wawancara, 6 Oktober 2017.

${ }^{31}$ Nabila, siswa kelas X-IPA-2, wawancara, 5 Oktober 2017.
} 
disampaikan kepala sekolah Nurhidayat bahw peran guru mata pelajaran agama Islam (PAI) sangat penting untuk memberikan pendidikan multikultural di sekolah, karena di tangan guru PAI peserta didik bisa dikenalkan berbagai latar belakang masyarakat yang berbeda serta menghargai latar belakang masyarakat. Hal tersebut sesuai dengan QS. al-Hujurat: 13 bahwa manusia diciptakan di muka bumi ini tidak lain untuk saling mengenal antara satu dengan yang lainnya. Guru PAI memiliki tugas khusus mengenai memperkenalkan peserta didik tentang keberagaman dalam bentuk apapun. ${ }^{32}$

Peran guru PAI dalam menerapkan pendidikan multikultural yang ada di SMAN 1 Jombang dilakukan tentang sikap toleransi beragama dan penumbuhan budi pekerti. Hal tersebut dijelaskan guru agama Islam M. Sholahuddin ${ }^{33}$ berikut ini:

Penerapan pendidikan multikultural yang selama ini telah dilakukan adalah melalui peringatan hari besar Islam. Siswa yang non-muslim mereka mempunyai acara sendiri saat itu. Jadi acara yang dilakukan bersamaan, secara non-akademis melalui remaja masjid, kegiatan sekretaris bidang 1, tentang kegiatan keagamaan, istighosah. Sekolah juga memberikan fasilitas terhadap siswa non-muslim. Mereka juga mempunyai guru agama sendiri. Dalam hal kegiatan belajar mengajar sebelum memulai kegiatan pembelajaran pendidikan agama Islam pembelajaran, siswa membaca asmaul husna dan apabila jam pelajarannya ada dua jam maka diawali dengan membaca al-Qur'an satu lampir. Ketika ada pembelajaran PAI, maka yang non-muslim diberikan kebebasan untuk tetap berada di dalam kelas atau ke perpustakaan. Untuk siswa non-muslim mereka difasilitasi didatangkan guru agama mereka.

Hal tersebut juga ditegaskan dari hasil wawancara dengan Mukani ${ }^{34}$ selaku guru agama Islam berikut ini:

Sebelum pembelajaran dimulai, ditumbuhkan budi pekerti kepada para siswa, seperti sebelum pembelajaran siswa menyanyikan lagu Indonesia Raya, membaca surat-surat pendek serta membaca Pancasila. Dengan menyanyikan lagu Indonesia Raya dan membaca Pancasila mereka secara tidak langsung akan ternanam jika patriotismenya, rasa cinta terhadap Indonesia. Khusus untuk pelajaran PAI sendiri sebelum pembelajaran siswa membaca asma'ul husna, jika jamnya hanya satu jam saja. Tetapi jika ada dua

\footnotetext{
${ }^{32}$ Nurhidayat, kepala SMAN 1 Jombang, wawancara, 6 Oktober 2017.

${ }^{33} \mathrm{M}$. Sholahuddin, guru agama Islam SMAN 1 Jombang, wawancara, 5 Oktober 2017.

${ }^{34}$ Mukani, guru agama Islam SMAN 1 Jombang, wawancara, 11 Oktober 2017.
}

FALASIFA, Vol. 9 Nomor 2 September 2018 | 101 
jam pelajaran, maka siswa membaca al-Qur'an. Untuk yang non-muslim biasanya mereka membaca kitab suci mereka sendiri.

Keterangan dari Nurhidayat, kepala SMAN 1 Jombang, memperjelas hasil kedua wawancara di atas. Hasil wawancara dengan Nurhidayat ${ }^{35}$ tentang langkahlangkah pendidikan multicultural adalah berikut ini:

Langkahnya melalui intra, dalam pembelajaran melalui pembelajaran PKn dan pendidikan agama, seperti yang ada di dalam kepengurusan OSIS tidak hanya agama Islam saja yang menjadi pengurus, melainkan melibatkan nonmuslim dalam setiap kegiaatannya. Ada pelatihan khusus yaitu tentang bela negara supaya anak-anak toleran antar sesama.

Di sisi lain, Mukani ${ }^{36}$ mengatakan bahwasannya langkah yang ditempuh selama menjadi guru juga untuk menyebarluaskan pendidikan berbasis multikultural. Hal tersebut berdasarkan hasil wawncara berikut ini:

Langkah yang saya tempuh selama ini yaitu dengan cara mengembangkan $\mathrm{KI}$, KD yang ada di perangkat kelas XI semester 1 aspek al-Qur'an, yang tujuannya bagaimana menumbuhkan sikap toleransi antar siswa. Ada di surat Yunus ayat 40-41, dan surat al-Maidah ayat 142. Ketika pembelajarann siswa diajarkan untuk toleransi, contohnya ketika pembelajaran PAI, sejak dulu siswa yang non-muslim diberikan kebebasan, jika ada gurunya, maka siswa diberikan kebebasan untuk belajar di perpustakaan atau BP. Pada awal pelajaran ada kontrak belajar, yang nonmuslim di dalam kelas tidak apa-apa, di luar kelas juga tidak apa-apa, tetap ada absensi dari guru PAI, yang Islam wajib memakai kerudung, tetapi yang laki-laki pakai kopyah, terkecuali jika non-Islam maka tidak pakai kerudung.

Dengan bahasa berbeda, langkah ini juga dilakukan Ahmad Fathoni, guru PAI di SMAN 1 Jombang. Dia menjelaska bahwa langkah yang telah dilakukan adalah dengan cara menerapkan pendidikan multikultural melalui kegiatankegiatan kesiswaan, pelajaran yaitu kegiatan mengeksplorasi kreativitas siswa. "Dengan hal tersebut maka siswa tidak malu untuk menunjukkan identitas yang ia miliki," ujarnya. ${ }^{37}$

Langkah-langkah yang telah ditempuh oleh ketig guru PAI antara satu dengan yang lainnya berbeda-beda. Setiap guru memiliki caranya masing masing

\footnotetext{
${ }^{35}$ Nurhidayat, kepala SMAN 1 Jombang, wawancara, 6 Oktober 2017.

${ }^{36}$ Mukani, guru agama Islam SMAN 1 Jombang, wawancara, 11 Oktober 2017.

${ }^{37}$ Ahmad Fathoni, guru agama Islam SMAN 1 Jombang, wawancara, 9 Oktober 2017.
}

102 | FALASIFA, Vol. 9 Nomor 2 September 2018 
dalam menerapkan pendidikan agama yang berbasis multikultural. Ketika mereka menerapkan pendidikan multikultural, tentunya ada faktor penghambat dan faktor pendukung pendidikan multukultural. Menurut Mukani, mengenai faktor pendukung dan penghambat dalam menerapkan pendidikan multikultural adalah bahwa faktor kendala yang selama ini dialami relatif tidak ada. Sedangkan untuk faktor pendukungnya sendiri yaitu prasarana yang telah terpenuhi. Tantangan yang selama ini terjadi adalah pemahaman anak-anak terkadang belum menguasai konsep, tetapi sudah melaksanakan dan sudah mempraktikkan, tetapi pemahamannnya belum maksimal. ${ }^{38}$

Menurut Ahmad Fathoni, dalam menerapkan pendidikan multikultural, penghalangya tidak ada. Siswa bisa berdampingan dengan beda agama. Hal tersebut terjadi karena kepemimpinan dari kepala sekolah itu sendiri, rasa solidaritas guru dan kesadaran dari siswa itu sendiri. "Pendukungnya, pada pelajaran PKn ada pembiasaan penguatan karakter bangsa, melafadkan Pancasila dan pembiasaan sifat-sifat positif," ujarnya. ${ }^{39}$

M. Sholahuddin mengatakan agak berbeda dengan apa yang disampaikan Mukani dan Ahmad Fathoni. Dia menjelaskan bahwa karena SMAN 1 Jombang adalah sekolah umum, maka kurang mendapatkan support dan guru yang lain, kurang ada kekuatan secara masif kepada siswa. "Faktor pendukungnya adalah kebijakan yang mengarah, ditegaskan pada K-13 lebih nampak pada bidangnya, input yang ada atau siswa yang ada mudah diarahkan, karena suasana yang mendukung," paparnya. ${ }^{40}$

Guru PAI, dalam menerapkan pendidikan multikultural melalui pembelajaran, terjadi baik yang ada di dalam kelas ataupun diluar kelas. Menurut Hafid, guru PAI sudah sangat berperan, seperti halnya ketika pembelajaran PAI guru mampu menyambungkan pada nilai-nilai Pancasila, sosial dan budaya serta membangun karakter siswa. ${ }^{41}$ Pendidikan multikultural sangat perlu diberikan kepada siswa, sebagaimana yang disampaikan M. Sholahuddin, ${ }^{42}$ berikut ini:

Pendidikan multikultural sangat perlu dan secara normatif pendidikan multikultural harus diberikan di sekolah. Tujuan dari diberikannya

\footnotetext{
${ }^{38}$ Mukani, guru agama Islam SMAN 1 Jombang, wawancara, 11 Oktober 2017.

${ }^{39}$ Ahmad Fathoni, guru agama Islam SMAN I Jombang, wawancara, 11 Oktober 2017.

${ }^{40}$ M. Sholahuddin, guru agama Islam SMAN 1 Jombang, wawancara, 6 Oktober 2017.

${ }^{41}$ Hafid, siswa kelas XII-IPA-2, wawancara, 6 Oktober 2017.

${ }^{42}$ M. Sholahuddin, guru agama Islam SMAN 1 Jombang, wawancara, 5 Oktober 2017.
}

FaLASIFA, Vol. 9 Nomor 2 September 2018 | 103 


\section{Elik Khoirun Nisa-Mukani}

pendidikan multikultural di sekolah adalah agar anak bisa mengetahui kemajemukan yang ada karena Islam rahmatal lil 'alamin. Manfaat diberikannya pendidikan multikultural adalah bisa melahirkan iklim yang kondusif di sekolah serta kenyamanan dalam pembelajaran, sehingga antara siswa tidak ada sekat satu dengan yang lainnya. Sehingga siswa bisa menempatkan yang semestinya untuk bekal mereka di kehidupan mendatang.

Pernyataan serupa ditegaskan Mukani. Pendidikan multikultural, menurutnya, sangat perlu, karena di kurikulum 2013 kelas XI semester ganjil ada KD yang menjelaskan tentang toleransi, yang bersumber dari al-Qur'an. Itupun harus dipupuk sedini mungkin untuk membangun Indonesia sesuai dengan bhinekaam tunggal Ika. Sedangkan untuk manfaat dari pendidikan multikultural adalah siswa terbuka, menghargai kebhinekaan, adat dan agama maupun Suku. Siswa yang dari luar Jawa diharuskan belajar bahasa Jawa, karena wawasan siswa sudah terbuka maka ketika ada temannya yang keluar kelas, maka yang lainnya tidak ada yang komplain bahwa yang keluar adalah siswa non-Islam. Dengan pemahaman yang baik, di suatu saat ketika mereka menjadi pemimpin, tidak mengambil kebijakan yang menguntungkan satu golongan saja, tetapi mereka mampu mempertimbangkan yang baik, karena mereka sudah terbiasa. "Contoh konkritnya yang terjadi di sini adalah dulu ada ketua majelis perwakilan kelas yang gamanya Hindu, tetapi dia terpilih secara aklamasi, karena sikapnya dia baik. Di sini juga ada peringatan khitan massal dua tahun sekali, dulu ketika ada Idhul Adha yang non-muslim, namun guru harus mencontohkan bahwasannya toleransi harus tetap ada batasan," ujarnya. ${ }^{43}$

Menurut Ahmad Fathoni, guru PAI yang lain, pendidikan multikultural perlu diberikan kepada siswa, karena pada prinsipnya pendidikan multikultural adalah pendidikan yang berbeda dalam hal suku, etnis, agama dan budaya, sehingga dengan perbedaan itu siswa diharapkan bisa menambah wawasan dan diharapkan mulculnya rasa saling menghargai. "Sedangkan untuk manfaat dari pendidikan multikultural sendiri agar muncul sifat saling menghormati dan menghargai antara sesama, sehingga tujuan sekolah bisa tercapai dan menimbulkan perkembangan yang aman dan tenteram," jelasnya. ${ }^{44}$

Kondisi ini menguntungkan semua warga sekolah dalam mewujudkan visi misi sekolah. Menurut Saidun, waka kesiswaan, situasiyang kondusif ini berimbas

\footnotetext{
${ }^{43}$ Mukani, guru agama Islam SMAN 1 Jombang, wawancara, 11 Oktober 2017.

${ }^{44}$ Ahmad Fathoni, guru agama Islam SMAN 1 Jombang, wawancara, 9 Oktober 2017.
}

104 | FALASIFA, Vol. 9 Nomor 2 September 2018 
kepada kenyamanan peserta didik dalam mengikuti proses pembelajaran. "Alhamdulillah, selama ini tidak pernah ada konflik di sini yang terjadi antar sesame warga sekolah, apalagi bersumber dari masalah agama, karena semua yang di sini saling memahami dan menghargai bahwa perbedaan itu membawa keindahan dan rahmat," paparnya. ${ }^{45}$

Berdasarkan uraian di atas dapat disimpulkan bahwa peran guru PAI dalam menerapkan pendidikan multikultural yang ada telah sesuai dengan apa tujuan pendidikan multikulkural. Hal tersebut berdasarkan kegiatan belajar mengajar yang berlangsung. Hubungan antara siswa berjalan dengan baik, di sekolah tersebut tidak pernah ada konflik. Guru PAI menerapkan pendidikan multikultural di antaraya sebelum pembelajaran siswa membaca asma'ul husna, membaca kitab suci, toleransi antar sesama dan penumbuhan budi pekerti. Pada saat digelar peringatan hari besar Islam, untuk siswa yang non-muslim mereka membuat acara tersendiri di ruang kelas tertentu dengan dipimpin guru agamanya sendiri, juga mereka satu sama lain saling membantu ketika ada kegiatan.

Pendidikan agama Islam berbasis multikultural adalah model pendidikan yang menekankan pada nilai-nilai moral, seperti kasih sayang, cinta seseorang, tolong menolong, toleransi, menghargai keberagaman dan sifat saling menjunjung kemanusiaan. Ini dikarenakan perbedaan yang terjadi adalah sebuah keniscayaan, bukan sebuah kenistaan. Upaya untuk merawat dan melestarikan perbedaan itu harus terus dipupuk dalam benak setiap generasi penerus bangsa.

Pendidikan Islam berwawasan multikultural adalah suatu pendidikan yang membuka visi dan cakrawala yang lebih luas. Mampu melintas batas kelompok etnis atau tradisi budaya dan agama sehingga mampu melihat "kemanusiaan" sebagai keluarga yang memiliki perbedaan ataupun kesamaan cita-cita. Nilai-nilai pendidikan Islam berbasis multikultural minimal ada tujuh, yaitu nilai andragogi, nilai perdamaian, nilai inklusivisme, nilai kearifan, nilai toleransi, nilai humanisme dan nilai kebebasan. ${ }^{46}$

Nilai andragogi mengarapkan sekolah mampu mengubah keterpurukan manusia dari berbagai sudut yang mengakibatkan diambang kehancuran. Guru befungsi sebagai fasilitator dan bukan menggurui. Pendidikan menjadi sarana bagi ajang kreativitas, minat dan bakat peserta didik, visi pendidikan yang demokratis, liberal, kemudian menjadi kebutuhan yang pokok ketika masih memiliki satu citacita tentang pentingnya membangun kehidupan yang humanis.

\footnotetext{
${ }^{45}$ Saidun, waka kesiswaan SMAN 1 Jombang, wawancara, 9 Oktober 2017.

${ }^{46}$ Yaya Suryana dan H.A. Rusdiana, Pendidikan Multikultural (Bandung: CV Pustaka Setia, 2015), 323.
}

FALASIFA, Vol. 9 Nomor 2 September 2018 | 105 


\section{Elik Khoirun Nisa-Mukani}

Nilai perdamaian menempatkan Islam sebagai agama rahmatal lil 'alamin, yaitu sebagai agama yang memiliki misi menyebarkan kedamaian kepada semua umat manusia. Islam melarang jihad terhadap orang-orang non-Islam yang menyatakan ingin hidup rukun dan damai bagi umat Islam. Sikap hidup dengan agama lain telah dicontohkan Nabi Muhammad Saw yang tidak melancarkan jihad terhadap orang minoritas, yaitu Yahudi, karena mereka telah menyatakan diri untuk terikat dalam kontrak kenegaraan dalam Piagam Madinah.

Nilai inklusivisme memberikan formulasi bahwa Islam adalah agama terbuka. Islam menolak eksklusivisme, absolutisme dan memberikan apresiasi yang tinggi terhadap pluralisme. Hal ini perlu diberikan kepada peserta didik dalam PAI agar mampu melahirkan sikap inklusif sekaligus toleransi positif di kalangan umat beragama, sejalan dengan semangat QS. Ali Imran: 64. Sikap inklusif ada karena al-Qur'an mengajarkan paham religius plurality. Bagi orang Islam, dianut suatu keyakinan bahwa sampai hari ini pun di dunia ini akan terdapat keragaman agama. ${ }^{47}$

Nilai kearifan menyajikan bahwa Islam memberikan kebebasan kepada manusia untuk mencari sendiri berbagai hal yang dapat disebut prinsip sekunder. Dalam Islam kearifan dapat dipelajari melalui ajaran sufi. Sufi berarti kebijakan atau kesucian, yaitu suatu cara membersihkan hati dari kelakuan buruk. Sufi mengajari manusia untuk membersikan nafsu, hati dan jiwa melalui pendekatan esoteris melihat Allah Swt tidak untuk ditakuti, tetapi untuk dicintai.

Nilai toleransi berarti sikap membiarkan, mengakui dan menghormati keyakinan orang lain tanpa memerlukan persetujuan. Pendidikan agama Islam perlu segera menampilkan ajaran-ajaran Islam yang toleran melalui kurikulum pendidikannya dengan tujuan menitikberatkan kepada pemahaman dan upaya untuk bisa hidup dalam konteks berbeda agama dan budaya, baik secara individual maupun secara kelompok. Toleransi dalam bahasa Arab disebut dengan tasamuh, yang berarti menghormati pegangan dan pendapat orang lain. Hal ini sudah ditegaskan dalam QS. al-Kafirun: 6.

Nilai humanism mengajarkan bahwa Islam adalah agama universal yang menjunjung tinggi nilai-nilai kemanusiaan, persamaan hak dan mengakui adanya keragaman latar belakang budaya dan kemajemukan. Multikultural menurut Islam adalah sebuah aturan Tuhan (sunnatullah) yang tidak akan berubah, juga tidak mungkin dilawan atau diingkari. Setiap orang akan menghadapi kemajemukan di manapun dan dalam hal apapun. Dalam Islam manusia dipandang dengan arti persamaan derajat tanpa membedakan etnik, ras, jenis kelamin, pola pemikiran

${ }^{47}$ Ibid, 329.

106 | FaLASIFA, Vol. 9 Nomor 2 September 2018 
dan golongan. Ini dikarenakan di hadapan Allah Swt, hanya ketakwaanya yang membedakan mereka antara satu dengan lainnya.

Sedangkan nilai kebebasan adalah unsur dasar teologi pembebasan yang berasal dari spirit dasar Islam dilahirkan. Kebebasan untuk memilih dan kebebasan untuk keluar menuju kehidupan yang lebih baik serta kebebasan untuk menghubungkan dirinya dengan kondisi yang berubah-ubah secara berarti. Teologi pembebasan memberikan manusia kebebasan ini untuk melampaui situasi kekiknian yang sedang dihadapi, dalam mengaktualisasikan potensi-potensi kehidupan yang baru dalam kerangka kerja sejarah. ${ }^{48}$

Berdasarkan kondisi riil di SMAN I Jombang dan kajian penguatan karakter melalui pendidikan agama Islam berbasis multikultural di atas, Nampak bahwa fenomena yang terjadi sudah sesuai dengan kajian teori. Hal ini merupakan perkembangan dan kemajuan tersendiri bagi dunia pendidikan, sehingga eksistensinya harus tetap dijaga secara konsisten. Sebagai generasi penerus bangsa, upaya ini akan menjadi sebuah perjuangan dalam mengisi pembangunan Indonesia, dengan tanpa meninggalkan identitas diri yang tetap melekat.

\section{KESIMPULAN}

Berdasarkan hasil penelitian dan pembahasan di atas, dapat disimpulkan bahwa kondisi yang ada di SMA Negeri l Jombang sangat beragam. Keberagaman tersebut meliputi keberagam suku, agama, status sosial serta pola pikir. Suku yang ada di sekolah tersebut meliputi suku Padang, Jawa, Bugis dan Madura. Sedangkan dalam hal agama, agama yang ada disana yaitu agama Islam, Katolik dan Protestan. Keberagaman yang ada tidak membuat mereka terpecah belah sehingga menimbulkan konflik. Tetapi dengan adanya perbedaan mereka saling memahami, menghormati dan toleransi antara satu dengan yang lainnya. Pihak pengelola sekolah memberikan kebebasan kepada setiap individu untuk beraktualisasi sesuai dengan keyakinan masing-masing.

Guru agama Islam berperan penting dalam menerapkan pendidikan multikultural. Hal tersebut berdasarkan kegiatan belajar mengajar yang berlangsung di sekolah. Hubungan antara siswa berjalan dengan baik, di sekolah tersebut tidak pernah ada konflik. Guru PAI menerapkan pendidikan multikultural di antaranya memberikan kebebasan kepada peserta didik yang beragama nonIslam untuk tetap di kelas atau meninggakan kelas saat pelajaran PAI berlangsung. Pada peringatan hari besar Islam, para siswa yang beragama non-Islam ini juga

${ }^{48}$ Umiarso dan Zamroni, Pendidikan Pembebasan Dalam Perspektif Barat dan Timur (Yogyakarta: Ar-Ruzz Media, 2011), 118.

FALASIFA, Vol. 9 Nomor 2 September 2018 | 107 
Elik Khoirun Nisa-Mukani

membantu pelaksanaan kegiatan. Bagi siswa yang beragama non-Islam ataupun berasal dari suku minoritas, semua mengakui tidak pernah mengalami diskriminasi berdasarkan status agama dan suku yang disandangnya.

\section{DAFTAR PUSTAKA}

Aly, Abdullah. Pendidikan Islam Multikultural di Pesantren. Yogyakarta: Pustaka Pelajar, 2011.

Arikunto, Suharsimi. Prosedur Penelitian. Jakarta: Rineka Cipta, 2010.

Baidhawy, Zakiyuddin. Pendidikan Agama Berwasan Multikultural. Jakarta: PT Gelora Aksara Pratama, 2003.

Darajat, Zakiyah. Ilmu Pendidikan Islam. Jakarta: Bumi Aksara, 2011.

Hamalik, Oemar. Proses Belajar Mengajar. Jakarta: Bumi Aksara, 2015.

Haryati, Tri Astutik. "Islam dan Pendidikan Multikultural," Jurnal Tadris, Vol. 2 (2009).

http://www.nu.or.id/post/read/78490/junjung-toleransi-antar-umat-beragamajombang-tuan-rumah-ayic-2017. Diakses 22 Juni 2017.

Ibrahim, Rustam. "Pendidikan Multikultural: Pengertian, Prinsip dan Relevansinya dengan Tujuan Pendidikan Islam. Jurnal Addin, Vol. 1.

Machfud, Choirul. Pendidikan Multikultural. Yogyakarta: Pustaka Pelajar, 2016.

Moleong, Lexy J. Metodologi Penelitian Kualitatif. Bandung: Remaja Rosdakarya, 2010.

Naim, Ngainun dan Ahmad Syauqi. Pendidikan Multikultural Konsep dan Aplikasi. Yogyakarta: Ar-Ruuz Media, 2010.

Narbuko, Colid dkk. Metodologi Penelitian. Jakarta: PT. Bumi Aksara, 2008.

Nata, Abudin. Filsafat Pendidikan Islam. Jakarta: Katalog dalam Terbitan, 2005.

Observasi, 6 Oktober 2017.

Ramayulis. Ilmu Pendidikan Islam. Jakarta: Kalam Mulia, 2010.

Sagala, Syaiful. Kemampuan Profesional Guru dan Tenaga Kependidikan. Bandung: Alfabeta, 2009.

Sapendi. "Internalisasi Nilai-nilai Multikultural dalam Pembelajaran Pendidikan Agama Islam di Sekolah.” Raheema: Jurnal Studi Gender dan Anak, (tt.).

Suryana, Yaya dan H.A. Rusdiana, Pendidikan Multikultural. Bandung: CV Pustaka Setia, 2015.

Tafsir, Ahmad. Ilmu Pendidikan Dalam Perspektif Islam. Bandung: PT. Remaja Rosdakarya, 2010.

Umiarso dan Zamroni. Pendidikan Pembebasan Dalam Perspektif Barat dan Timur. Yogyakarta: Ar-Ruzz Media, 2011. 
Usman, Moh. Uzer. Menjadi Guru Profesional. Bandung: Rosdakarya, 2010.

\section{Hasil Wawancara}

Adam, siswa kelas X-IPA-2, 5 Oktober 2017.

Ahmad Fathoni, guru agama Islam SMAN 1 Jombang, 9 dan 11 Oktober 2017.

Fatih, siswa kelas XI-IPA-2, 6 Oktober 2017.

Hafid, siswa kelas XII-IPA-2, 6 Oktober 2017.

Mukani, guru agama Islam SMAN 1 Jombang, 4, 6, 11 Oktober 2017.

M. Sholahuddin, guru agama Islam SMAN 1 Jombang, 5 dan 6 Oktober 2017.

Nabila, siswa kelas X-IPA-2, 5 Oktober 2017.

Nurhidayat, kepala SMAN 1 Jombang, 6 Oktober 2017.

Saidun, waka kesiswaan SMAN 1 Jombang, 9 Oktober 2017.

Yohana, siswa kelas XI-IPA-2, 6 Oktober 2017. 
Elik Khoirun Nisa-Mukani

110 | FaLASIFA, Vol. 9 Nomor 2 September 2018 